\title{
Practices Adopted by Parents of Children with Dysphasia in Inclusive Primary School
}

\author{
France Beauregard \\ Université de Sherbrooke
}

\begin{abstract}
Parental involvement is essential in the context of inclusive schooling; however, few studies have looked at how parents of children with disabilities become involved in their child's school experience. This study explored the practices adopted by parents of children with dysphasia when their children were integrated into inclusive classes in primary school. Eleven parents took part in semi-structured interviews. Epstein's typology was used to classify the practices that emerged from their responses. The results showed that these practices were interdependent. The intentions underlying any one practice can differ depending on the parents, just as any one intention can be represented in a variety of practices. We identified individual and environmental factors that influence the practices.
\end{abstract}

In Canada, each province is responsible for its own laws governing education, curricula, and teaching programs. Quebec's most recent Education Act was passed in 1999 (Government of Quebec, 1999). The same year, the Ministry of Education adopted its new school adaptation policy (Ministère de l'Éducation du Québec, 1999) ${ }^{1}$. In both documents, the government reiterated its intention to make more room for parental involvement and for the inclusion of students with disabilities in neighbourhood schools. Since then, several studies have investigated parents' and teachers' perceptions of Quebec's new school context. While these studies targeted different populations and employed different methods, they reached some common conclusions. Quebec's Conseil de la famille et de l'enfance [Council on Family and Childhood] (2001) and Conseil supérieur de l'éducation [Higher Education Council] (2002) observed that even though parents and teachers have seen improvements, particularly in the development of the individual education plan (IEP) and the introduction of measurement systems to facilitate school evaluations, many problems persist. Thus, some studies noted that parents saw themselves as having to defend their children's rights. According to some of these studies, professionals often perceived parents as members of associations and seekers of services who wanted to interfere with their work (Beauregard, 2002; Bouchard \& Kalubi, 2003; Larrivée, Kalubi, \& Terrisse, 2006; Rousseau, Dionne, Vézina, \& Drouin, 2009).

\footnotetext{
${ }^{1}$ In Quebec, the term generally used is “integration scolaire," without specifying whether this is mainstreaming or inclusion.
} 


\section{Problem}

Teachers of students with special needs have reported having heavier workloads than teachers with homogenous classes. They are expected to get to know their students' problems and needs and then to adapt their teaching methods and materials accordingly. Yet in inclusive classrooms, teachers have not only students with special needs, but also regular students for whom they are equally responsible (Beauregard, 2006; Conseil supérieur de l'éducation, 2002; Kabano, 2000; Larrivée et al., 2006). While some have questioned the relevance of developing inclusive school settings for children with disabilities, formal authorities have produced documents aimed at facilitating parental involvement and the inclusion of students with disabilities into regular schools (Conseil de la famille et de l'enfance, 2001; Ministère de l'Éducation du Québec, 2003a, 2003b, 2004). This was done without, however, clearly defining what was meant by parental involvement in the context of inclusive schooling.

Both education and research fields have, for many years, been interested in the family-school relationship and parents' involvement in their children's school experience (Christenson \& Reschly, 2009; Crozier, 2000; Epstein, 1992; Lawrence-Lightfoot, 1978; Organisation de coopération et de développement économique, 1995; Sharrock, 1970). Empirical studies have shown the importance of such involvement in terms of, among other things, improving the child's self-respect, reducing absenteeism, and increasing appropriate behaviours in school (e.g., Christenson \& Reschly, 2009; Epstein, 2001; Hoover-Dempsey et al., 2005). These studies helped identify variables that influence parental involvement. Among them are socioeconomic environment, parents' education, number of children, both parents being employed, and the child's learning or social difficulties. Authors also noted that parental involvement can vary depending on parents' beliefs, representations they have of their child and role toward that child, their feelings of competency, their expectations of the child and school, and their perceptions of the situation, among other things (Coleman, 1998; Crozier, 2000; Hoover-Dempsey et al., 2005; Lareau, 1997). There are clearly many ways for parents to become involved and this involvement can vary from one parent to another.

\section{Parental Involvement in an Inclusion Context}

Parental involvement is important for average-achieving students, but essential for children with special needs - taught in both special classes and regular classes. In Quebec, the proportion of children considered to have special needs - at pre-school, elementary, and secondary levels - has grown from $13.5 \%$ in $2003-2004$ to $18.4 \%$ in $2009-2010$. The statistics also indicate that inclusion in schools is increasing: In 2003-2004, 60\% of students with special needs were in regular schools, but by 2009-2010 that proportion had reached $65.1 \%$ (Ministère de l'Éducation, du Loisir et du Sport du Québec, 2010). Thus, the population of students with special needs in regular classes has grown by nearly $20 \%$.

For inclusive schooling of children with disabilities to be successful, certain conditions are essential. Researchers have investigated the family-school relationship in the inclusion context (i.e., Andrews \& Lupart, 2000; Bennett, Lee, \& Lueke, 1998; Beveridge, 2005; Conseil supérieur de l'éducation, 1996; Erwin \& Soodak, 2008; Hick \& Thomas, 2008; Organisation de coopération et de développement économique, 1995; Snell \& Brown, 2005; Turnbull, Turnbull, Erwin, \& Soodak, 2006) and found that an effective one is essential to successful inclusion. Parents can provide information on their children's disabilities to help teachers intervene more appropriately. Teachers can explain to parents the approaches used in class so parents can apply them at home during study and homework time.

Several studies, however, have shown that parents face numerous obstacles when trying to become involved in the school experience of their child who is included in a regular class, such as contradictory expectations, confrontational contact, and some teachers' lack of 
training in disabilities (Conseil supérieur de l'éducation, 1996; Cook \& Swain, 2001; Evans \& Lunt, 2002; Leyser \& Kirk, 2004; Pivik, McComas, \& Laflamme, 2002). Although these studies helped identify facilitating factors and obstacles to the inclusion of students with special needs, they nevertheless had certain shortcomings. These studies employed different methodologies and rarely defined what was meant by inclusion. Some of the studies combined parents whose children had different types of disabilities (e.g., intellectual disabilities, dyslexia, physical disabilities) or ranged in age from 3 to 21 years. Yet the needs of children with different types of disabilities or at different ages are not the same. It is therefore difficult to transfer the results of such studies to any specific population, much less to generalize them to all students with disabilities.

Given the enormous and diverse population of children with special needs, we targeted, for our study, parents of children with dysphasia. We made this choice for several reasons. First, dysphasia is poorly understood by the teaching community. It is not uncommon for parents to be more knowledgeable about it than teachers. Also, it is a disability that is often imperceptible, and behaviours considered inappropriate in school are often interpreted as behaviour problems. This sometimes leads to conflict with parents who see these behaviours as related to dysphasia rather than wilful choices on the part of students. Finally, as we will show, there has been little research on the experience of parents of children with dysphasia who are integrated into regular classrooms.

\section{Dysphasia and its Impacts}

Dysphasia is a communication disorder affecting either oral expression alone or oral expression and comprehension. It results from a brain dysfunction that significantly limits understanding, language development, and speech, thereby inhibiting children's ability to communicate verbally and to perform activities appropriate to their age and environment (Ordre des orthophonistes et audiologistes du Québec, 2010). It can create problems on the phonological, morphological, syntactical, pragmatic, and semantic levels. It is always accompanied by cognitive disorders such as problems with generalization, abstraction, temporality, and perception (Lussier \& Flessas, 2005). Moreover, the diagnosis can become complicated by the presence, to varying degrees, of attention deficit disorders, with or without hyperactivity. In 2005, Quebec's association of speech therapists - the professionals responsible for diagnosing dysphasia in that province-updated the definition of dysphasia and adopted a new term, Primary Language Disorder ( $\mathrm{PLD}^{2}$; Beaulieu \& Buttiens, 2005). Although the term dysphasia is still commonly used, the new term PLD is increasingly used in the rehabilitation community but not in the education community.

In Quebec, a recent study showed that 7.4\% of children aged $4.5-5$ years had been diagnosed with a PLD-dysphasia (Thordardottir, Kehayia, Lessard, Sutton, \& Trudeau, 2010). According to Thordardottir and colleagues, the prevalence was higher than government authorities had believed; in fact, the Ministry of Education believed that less than 1\% of children had dysphasia. Consequently, this population, for whom it was the government's responsibility to provide services to ensure their success in school, had increased.

Dysphasia affects many aspects of children's lives, particularly in relation to school, social interaction, and family. Many researchers have looked at the difficulties these children encounter. Their vocabulary is often limited, their language less mature than other children their age, and they have difficulties with reading comprehension and understanding the subtleties of language (Catts, Bridges, Little, \& Tomblin, 2008; Hoffman \& Gillam, 2004; Montgomery, 2006). Consequently, they have problems learning verbs (Kelso, Fletcher, 2007; Riches, Tomasello, \& Conti-Ramsden, 2005) and likewise have difficulty with oral

\footnotetext{
${ }^{2}$ In the English environment, these children may be compared to those diagnosed with specific language impairment (SLI).
} 
presentations, such as in telling stories or taking oral tests (Epstein \& Phillips, 2009; Peets, 2009), or in composing texts (Ferouhi, 2007). For example, in both oral and written expression, they may confuse genders, singular/plural usages, and verb tenses or they may repeat words. Cognitive difficulties may appear, for example, in mathematics (Knox, 2002). In addition, because language is related to social skills, some children experience social problems, particularly with respect to social language (Botting \& Conti-Ramsden, 2008; Fujiki, Brinton, \& Todd, 1996), which translate into behaviour problems or lower self-esteem for some children (Coster, Goorhuis-Brouwer, Nakken, \& Spelberg, 1999; Wadman, Durkin, \& ContiRamsden, 2008). They are also at greater risk of being bullied (Knox \& Conti-Ramsden, 2003) or of developing mental health problems in adolescence (Conti-Ramsden \& Botting, 2008). Finally, studies have shown that, even with therapy, some children with dysphasia continue to experience problems in their daily lives even into their adult years (Nippold \& Schwarz, 2002; Palikara, Lindsay, \& Dockrell, 2009; Törnqvist, Thulin, Segnestam, \& Horowitz, 2009).

\section{Parents of Children with Dysphasia}

Even though research has produced a great deal of knowledge about children with dysphasia, relatively little focus has been placed on their parents. Three studies have explored the daily lives of these parents (i.e., Jupsin, 1996; Pratt, Botting, \& Conti-Ramsden, 2006; Saint-Pierre, 1997). These authors concluded that the parents were very worried about their children's futures, the support their children were receiving, their progress in school, and the needs of the other siblings in the family. Other researchers have looked at the impacts of a language stimulation program or at parents' language practices (i.e., Hammer, Tomblin, Zhang, \& Weiss, 2001; Proctor-Williams, Fey, \& Loeb, 2001). They observed that parents had different practices depending on whether or not their child had dysphasia. However, very few studies have looked at parents in relation to their children's schools.

In one quantitative study, Simkin and Conti-Ramsden (2009) analyzed the perceptions of parents of young adults with dysphasia regarding their children's progress in special classes. Those parents reported being generally satisfied with the services their children received, particularly with respect to educational aspects. However, they noted the nearabsence of services to help their children develop social skills and of support services for parents. In a qualitative study, Beauregard (2002) examined parents' perceptions in the context of inclusive schooling in Quebec. Findings indicated that communication between the school and the family of an included student with dysphasia can be somewhat difficult. The findings were similar to those from studies carried out among parents of children with special needs in regular classes, such as lack of knowledge on the part of the school personnel, especially about dysphasia (e.g., characteristics of dysphasia, problems, strengths, impacts of associated disorders) and about inclusion (e.g., laws and policies, complementary services, support); an increased workload for parents at home; and a perception among parents that their desire to become involved in their children's schooling was not well accepted, although the parents did not clearly explain what this involvement entailed.

In the current context in Quebec, in which (a) society is debating the issue of including children with special needs in regular classes; (b) the prevalence of a population has now been confirmed; and (c) parents are being encouraged to become involved, both in official documents and unofficially, it is important to know what practices parents adopt to carry out their responsibilities toward their children with dysphasia. This, therefore, is our research question: What are the practices adopted by parents of children with dysphasia in inclusive primary schooling? 


\section{Theoretical Framework}

Many authors agree that parental involvement is multidimensional (Epstein, 1992, 2001; Fan \& Chen, 2001). It is often described in terms of parents' practices ${ }^{3}$ related to participation in their child's experience and their relationship with the school (Christenson \& Reschly, 2009; Conseil de la famille et de l'enfance, 2001; Hoover-Demspey et al., 2005). Epstein $(1992,2001)$ proposed a typology composed of six dimensions: (a) the family's obligations and support to their child; (b) home-school communication; (c) the family's involvement in school life; (d) parental involvement in the child's schoolwork at home; (e) parental participation in the decision-making process and in the management and defence of the child's interests (advocacy); and (f) community partnership with the school, business, and other local organizations. For each dimension, Epstein presented a series of activities or practices that parents adopted when they became involved in their children's schooling. This typology is helpful to capture parental practices in the educational experience of a child without any disability. It can also be useful for identifying parental practices in an inclusion context, yet very few studies have used it for this purpose.

\section{Epstein's Typology in an Inclusion Context}

For this study, we have grouped together parental practices found in research and professional literature as well as government documentation dealing with inclusion. Even when the literature deals with different populations (e.g., different ages, different disabilities), the activities identified are similar. Table 1 presents these practices, along with Epstein's suggestions for each dimension.

The first dimension, obligations and support, is very important for parents of children with disabilities. Given the specific needs of children with disabilities, this dimension is highest on the scale of parental practices. In addition to responsibilities for the child's basic well-being, it includes medical and therapeutic follow-up, specific physical care, all necessary assessments, and access to therapeutic material (Andrews \& Lupart, 2000; Bennett et al., 1998; Lipsky, 1989; Rousseau et al., 2009; Snell \& Brown, 2005; Turnbull et al., 2006). These responsibilities add to the parents' burdens, leaving them less time to participate in their child's school life. Some authors noted that parents view themselves as their child's manager on the medical, educational, social, family, and personal fronts and act accordingly (Brophy, Webb, \& Hancock, 1998; Grove \& Fisher, 1999).

For parents of children with disabilities, the components of the dimensions homeschool communication and family involvement in school life are of a more medical nature. In other words, the information shared or the involvement of parents in school life will be geared toward shedding light on their children's medical, social, and academic difficulties (Andrews \& Lupart, 2000; Beauregard, 2002; Bennett et al., 1998; Beveridge, 2005; Erwin \& Soodak, 2008; Lipsky, 1989; Rousseau et al., 2009; Sands, Kozleski, \& French, 2000; Snell \& Brown, 2005; Turnbull et al., 2006). The authors thus observe that these parents view themselves as mediators between the child and the school. They see their task as one of explaining how their child's disorder and disabilities affect his or her daily life. They will sensitize the school to their child's difference and make sure measures are implemented to meet the child's needs and facilitate inclusion (Brophy et al., 1998; Conseil supérieur de l'éducation, 1996; Cook \& Swain, 2001; Grove \& Fisher, 1999; Leyser \& Kirk, 2004).

The participation in decision-making and advocacy dimension operates at several levels: individual (parents and children), social (family, advocacy groups), community (social

\footnotetext{
${ }^{3}$ In this study, we define the practices as a set of behaviours or a system of socially recognized behaviours that may differ from one individual to another and one group to another.
} 
Table 1

Parental Practices in an Inclusion Context According to Epstein's Typology

\begin{tabular}{|c|c|c|}
\hline Dimensions & $\begin{array}{l}\text { Practices of Parents of Children } \\
\text { Without Disabilities }\end{array}$ & $\begin{array}{c}\text { Practices of Parents of Children } \\
\text { With Disabilities }\end{array}$ \\
\hline $\begin{array}{l}\text { Obligations toward } \\
\text { and support for the } \\
\text { child }\end{array}$ & $\begin{array}{l}\text { - Ensure the child's well-being: physical } \\
\text { health, nutrition, clothing, hygiene } \\
\text { - Talk with the child } \\
\text { - Take part in education groups }\end{array}$ & $\begin{array}{l}\text { - Ensure the child's physical well-being: clothing, } \\
\text { cleanliness, medication, orthotics } \\
\text { - Provide medical follow-up: evaluations, treatments } \\
\text { and therapies, appointments } \\
\text { - Transport the child for medical follow-ups } \\
\text { - Ensure a secure environment: modifications at } \\
\text { school, in the home, specialized transportation } \\
\text { - Ensure that the education received meets the child's } \\
\text { needs }\end{array}$ \\
\hline $\begin{array}{l}\text { Home-school } \\
\text { communication }\end{array}$ & $\begin{array}{l}\text { - Meet with the teacher } \\
\text { - Attend information sessions } \\
\text { - Obtain support for parents from the school }\end{array}$ & $\begin{array}{l}\text { - Meet with school professionals: location, time, } \\
\text { specify the role of each } \\
\text { - Share information about the child, his/her difficulties, } \\
\text { his/her disability } \\
\text { - Attend information sessions at school, join groups of } \\
\text { parents of children with disabilities } \\
\text { - Participate in developing the IEP: programs for the } \\
\text { child, changes to the curriculum } \\
\text { - Receive support provided to the parents by the } \\
\text { school } \\
\text { - Provide parental support at school }\end{array}$ \\
\hline $\begin{array}{l}\text { Family involvement in } \\
\text { school life }\end{array}$ & $\begin{array}{l}\text { - Attend training sessions } \\
\text { - Attend school activities } \\
\text { - Attend extracurricular activities } \\
\text { - Visit the classroom } \\
\text { - Volunteer }\end{array}$ & $\begin{array}{l}\text { - Share information on inclusion: raise awareness on } \\
\text { this approach, develop methods, create a positive } \\
\text { environment } \\
\text { - Volunteer }\end{array}$ \\
\hline $\begin{array}{l}\text { Parental involvement } \\
\text { in the child's school- } \\
\text { work at home }\end{array}$ & $\begin{array}{l}\text { - Supervise homework } \\
\text { - Support the work of the teachers }\end{array}$ & - Help with homework \\
\hline $\begin{array}{l}\text { Parental participation } \\
\text { in decision-making, } \\
\text { managing and defend- } \\
\text { ing the child's } \\
\text { interests (advocacy) }\end{array}$ & $\begin{array}{l}\text { - Support school programs } \\
\text { - Sit on decision-making committees, organ- } \\
\text { izational boards, parents' committees at the } \\
\text { school commission } \\
\text { - Engage in advocacy for children's interests }\end{array}$ & $\begin{array}{l}\text { - Participate in decision-making committees: advisory } \\
\text { committee for students with disabilities or with adap- } \\
\text { tation or learning difficulties, school committee } \\
\text { - Defend the child's needs, engage in advocacy: } \\
\text { defend the child's rights; act to ensure the child re- } \\
\text { ceives the necessary services; request programs, } \\
\text { evaluations, services, and adaptations for the child }\end{array}$ \\
\hline $\begin{array}{l}\text { Partnership with the } \\
\text { school, business, or } \\
\text { other local organiza- } \\
\text { tions }\end{array}$ & $\begin{array}{l}\text { - Meet with businesses, social clubs, commu- } \\
\text { nity organizations }\end{array}$ & $\begin{array}{l}\text { - Implement ways to integrate the child into the com- } \\
\text { munity: meet with organizations, go to information } \\
\text { sessions } \\
\text { - Seek help from community organizations: parent } \\
\text { associations, health and social services agencies }\end{array}$ \\
\hline
\end{tabular}

services, businesses), institutional (school board, Ministry), and legal (laws, jurisprudence). In the case of inclusive schooling, parents may be called to defend their child's right to be educated in a regular classroom (Andrews \& Lupart, 2000; Beauregard, 2002; Hick \& Thomas, 2008; Rousseau et al., 2009; Sands et al., 2000). Parents are defending not only that right, but also an educational philosophy and their child's right to take part in community life like any other individual (Beveridge, 2005; Grove \& Fisher, 1999; Lipsky, 1989; Snell \& Brown, 2005). As mentioned earlier, parents taking on these roles have additional tasks beyond those found in Epstein's $(1992,2001)$ parental involvement dimensions.

The community partnership dimension is also very important for parents of children with disabilities (Andrews \& Lupart, 2000; Snell \& Brown, 2005; Turnbull et al., 2006). For example, parents of children with dysphasia integrated into a regular class point out that some school personnel are unaware of the various organizations that care for persons with difficulties or that provide services the school cannot offer (Beauregard, 2002; Saint-Pierre, 1997). Parents must then take it upon themselves to find this information and obtain these services. 
It is clear from the literature that parents of children with disabilities have adopted not only the same practices as parents of children without disabilities, but also others specific to their own children's needs. In addition, it appears that the inclusive schooling context may complicate parents' involvement. Many parents reported encountering a variety of obstacles in relation to inclusion, such as some teachers' beliefs and attitudes about their child's capacities and strengths and the relevance of their child's inclusion in regular school, overly high expectations about what the child should be able to achieve, inadequate support measures for the child or teacher, and the school personnel's lack of knowledge about the child's disability (Beauregard, 2002; Bennett et al., 1998; Beveridge, 2005; Brophy et al., 1998; Hick \& Thomas, 2009; Rousseau et al., 2009).

In addition, in the literature we consulted, very few studies looked specifically at the dysphasia population. Yet, in terms of prevalence rates, on average 2 out of 25 students in any classroom have been diagnosed with dysphasia ${ }^{4}$. Some of these students are integrated into regular classrooms ${ }^{5}$. However, there is little information in the literature on their parents' practices, which raises many questions. What practices do these parents adopt in a context of educational inclusion? Are they the same for all these parents? What are the motivations underlying these practices? What factors influence them? In order to gather information to help answer these questions, our objectives were (a) to identify parental practices in the inclusion context and (b) to identify the factors influencing these practices.

\section{Methodology}

Given our research question and the lack of knowledge about the population targeted in this study, we adopted a qualitative paradigm (Lincoln \& Guba, 1985) for our exploratory research. In our study, we sought answers to questions that would inform us about parental practices that were undeniably interrelated with a particular context. In qualitative research, the approach must enable participants to recognize themselves in the results; be meaningful for the milieu concerned so people in that milieu can put the results to practical use; and take into account interactions between individuals and their environment (Paillé \& Mucchielli, 2008; Van der Maren, 1995). Therefore, because our goal was to gain knowledge and a better understanding of parental practices in the inclusive schooling of children with dysphasia, we adopted a descriptive-type qualitative research approach.

\section{Participants}

Eleven families participated in this study. Parents' ages ranged from 21 to 50 years, with most over the age of 30. Parents' education ranged from high school diplomas to postgraduate degrees. Six families had two working parents, either outside the home or selfemployed, while five had one parent at home full-time. All were two-parent families, and three were blended families with shared custody. The number of children in each family ranged from two to seven, including the child with dysphasia. Eight families had another child with dysphasia or a learning disability. Finally, two of the mothers worked in schools, one as a teacher and one as a technician in an elementary special education setting.

\section{Measures}

We used two instruments for data collection: (a) a personal information questionnaire that allowed us to describe the participants and (b) semi-structured interviews lasting ap-

\footnotetext{
${ }^{4}$ In Quebec, classes are made up of 20 to 30 students depending on the grade level.

${ }^{5}$ Because the classification model used by Quebec's Ministry of Education recognizes students as having dysphasia only if they are diagnosed with severe dysphasia (those with less severe dysphasia being considered as students with learning disabilities), we do not know the exact number of students with dysphasia integrated into regular classrooms.
} 
proximately 60 minutes that were audio-recorded. The open-ended questions were geared toward general practices as well as practices specific to each dimension of Epstein's typology. Before data collection, we validated the discussion framework with two University of Montreal professors who are experts in this field of research. We then pilot-tested the questions with a volunteer parent using the discussion grid to ensure the questions were significant and effective (Van der Maren, 1995). This step allowed us to fine-tune certain questions to focus more clearly on the information we were seeking on parental practices. The data gathered from this parent were not included in the analysis of our findings.

\section{Procedure}

Parents were recruited through organizations working with people with dysphasia: the Quebec Dysphasia Association (Association québécoise de la dysphasie), the Dysphasie + Association, and the Québec Learning Disabilities Association (Association québécoise des troubles d'apprentissage-AQETA). These associations contacted their members by letter or placed notices in their newsletters about our study. We also used the cascade method, asking people working in this field to talk about the research project (Van der Maren, 1995). For our study, we selected four regions of the Greater Montreal area whose populations had similar socio-demographic environments: Laurentides, Lanaudière, Montérégie, and Montreal. Our recruitment letter presented the research objectives, selection criteria, and how to contact the researcher. To be eligible, parents had to meet two criteria: their child (a) was diagnosed with dysphasia and (b) was, or had been, included in a regular elementary class for at least 1 year. Parents wishing to participate contacted the researcher by phone. During this call, the research objectives were reviewed, procedures for their participation were determined, and an appointment was set. Most interviews were carried out with mothers; in two families, fathers were also present. Data from these two latter families were treated as belonging to a single entity, the parents explaining that they lived their child's school inclusion together.

During the interview, parents were first given information about the study and the consent process; they were also asked for permission to record the interview. When the assurance of confidentiality and anonymity was established, they signed a consent form. These steps were intended to create a relationship of trust and respect between the researcher and parents so they could freely express their fears or expectations and ask questions. During the interview, parents were asked first to describe broadly their role in their child's inclusion at school. Then they were asked specifically about their role in relation to their child, the teacher, the school team, the school environment, and the community. At the end of the interview the researcher summarized parents' comments and asked if they wished to add anything.

\section{Data Analysis}

The analytical approach selected for this study was discourse analysis, a qualitative method used to describe, clarify, understand, and interpret a reality (Denzin \& Lincoln, 2005). We applied Paillé and Mucchielli's (2008) continuous thematic analysis as it allows for cross-referencing within a discussion and between discussions. We used ATLAS.ti software (Muhr, 2002) to code the data collected. Data were coded in three ways. The first coding was done from the questions, with each response being linked directly to a matching code. In the second, data were matched to dimensions of Epstein's typology of practices. The third coding dealt with new data and categories that emerged from participants' responses but were not mentioned in the literature.

The analysis grid was validated using a cross-coding process. After the researcher had done a first coding, sense units were cross-coded by a pair of coders (Denzin \& Lincoln, 2005; Van der Maren, 1995). They were provided with matrices that included sense units se- 
lected randomly for each theme (approximately $10 \%$ of all sense units) as well as the coding grid with the definitions of the themes and matching categories. We obtained an average concordance rate of $77 \%$ between the cross-coders and the researcher and reached unanimity after discussion among the coders. These results correspond to the levels of consistency recommended for cross-coding (Miles \& Huberman, 2003).

\section{Results}

Using Epstein's typology, we were able to categorize the practices that emerged from the parents' statements. In presenting the results, we first show the number of statements associated with each dimension of Epstein's typology. From this, it can be seen that some dimensions were more important than others for parents of children with dysphasia. Then, the tables that follow indicate the practices seen for each dimension. There again, it is clear that certain practices were more popular than others. Table 2 shows the number of sense units for each dimension of Epstein's typology and the number of participants corresponding to them.

First, we observed that almost all parents reported adopting practices belonging to the home-school communication, obligations and support, and involvement in schoolwork at home dimensions. The home-school communication dimension was the most important, not only because all parents referred to it, but also because it had the most sense units (more than $58 \%$ ). If we examine the sense unit/parent ratio for the three dimensions with the most parents, we see that parents referred to communication practices, on average, approximately 15 times. This ratio dropped to 4.6 for the dimension obligations and support and to 2.5 for involvement in schoolwork at home. This illustrates the major importance for parents of the home-school communication dimension.

\section{Practices Related to Home-School Communication (Dimension 2)}

Not only was this dimension very important for the parents, but it was also the one with the greatest variety of practices. Table 3 shows the breakdown and frequency of each. First, one-third of all home-school communications were exchanges between the parent and a member of the school team; this was true for all the parents. These communications were specifically about the child with dysphasia and the purpose most often was to explain some of the child's behaviours:

We were explaining some of J's behaviours. We weren't trying to tell them what to do, but only to explain to them that $J$ is afraid of balls. If there are balls in the gym he will sit in a corner and put his hands over his ears. Loud noises, explosions, all of that scares him. (Parent 2)

Parents made the teacher and other staff aware of their child's particular characteristics. It was important to them that school personnel understand their child's behaviours and that they knew these actions were not caused by behaviour problems but rather by dysphasia. Sometimes the exchanges related to professional practices the parents' considered inappropriate

Table 2

Epstein's Typology: Dimensions in the Inclusion Context of Children with Dysphasia

\begin{tabular}{lcc}
\hline \multicolumn{1}{c}{ Dimensions } & Number of Sense Units & Number of Participants \\
\hline Home-school communication & 163 & 11 \\
Obligations and support & 46 & 10 \\
Involvement in schoolwork at home & 25 & 11 \\
Participation in decision-making and advocacy & 23 & 8 \\
Family involvement in school life & 17 & 7 \\
Community partnership & 5 & 5 \\
Total & 279 & 11 \\
\hline
\end{tabular}


Table 3

Practices Related to the Home-school Communication Dimension

\begin{tabular}{lcc}
\hline \multicolumn{1}{c}{ Dimensions } & Number of Sense Units & Number of Participants \\
\hline Communicate and inform & 43 & 11 \\
Participate in developing the IEP & 22 & 11 \\
Make requests & 20 & 10 \\
Serve as liaison between different professionals & 13 & 5 \\
Implement conditions & 11 & 6 \\
Discuss the child's academic classification & 10 & 7 \\
Provide reports, material & 10 & 5 \\
Inform on dysphasia & 10 & 4 \\
Take part in annual meetings & 9 & 8 \\
Make one's availability known & 8 & 6 \\
Receive information & 6 & 4 \\
Total & 162 & 11 \\
\hline
\end{tabular}

For them, this was a delicate situation, and they stressed the need for tact and diplomacy in order not to offend the other person. However, when that person's practices contradicted parents' beliefs, parents became more determined in their insistence:

He always had a paraprofessional, and I had to tell her, "look, he has a notebook that lists all the steps to do, he has to do them himself." Then, one time, he brought home a two-page text. I went back and said to the teacher, "We talked about this at the beginning of the year. It's impossible that he wrote these two pages; they were written by someone else. You're the teacher; I'd like you to deal with the paraprofessional and talk with her." (Parent 3)

The second type of practice that emerged was parental involvement in the IEP. All the parents were involved in these plans; however, the nature of their involvement varied. When parents recognized their children in the statements made by the staff, they had the impression that they had played an active role in the development of the plan:

\footnotetext{
They said to me, "so, the problems in reading are at this level," and they were exactly right. You could see that the special education teacher had evaluated [my child] because she knew what she was talking about. I was pleased, because I said to myself, "they've really taken the time to find out," especially the professionals: the teacher's assistant, the speech therapist, the remedial teacher. These three people were very open to what we brought and to what we were asking of them. (Parent 7)
}

From this statement, it is clear that the parent's satisfaction was because the school team gave her the opportunity to express herself. However, several other parents reported experiencing more difficult situations on different occasions. Thus, some had to make the request themselves for a meeting on the IEP, even though according to the law on education it is the responsibility of the school administration to call this meeting. Other parents reported that the meetings occurred at times when they were not available and they had to change their schedules. Finally, a few had the impression that the plan was prepared ahead of time and their presence was incidental:

It's the result of THEIR intervention plan. They meet BEFORE meeting the parents and they put together the WHOLE plan. Afterward, they come out of the meeting all together. They come to get you, and you sit there. They describe the plan to you, one by one. Whether you agree or not, it doesn't matter. That's not a jointly developed intervention plan. (Parent 9)

The parent interpreted this type of process as collusion intended to exclude parents from the actual development of the plan.

The third type of practice parents reported related to requests for meetings, either to explain their children's specific characteristics to the teacher, to clarify a point, or to develop the intervention plan. It might have been a request for an assessment by a school professional, for modification of teaching materials, or for conditions to facilitate school evaluations. 
Sometimes it was a meeting at which parents expressed their wish to be informed about everything related to their child, the objective being to avoid a situation becoming confrontational. In fact, for parents, one of the worst situations was when the IEP was developed during a period of conflict.

On the other hand, more than half the parents reported having to perform "supervision," by which they meant that they needed to ensure that the conditions required for their children's inclusion in school were actually in place. For example, some made sure the teacher knew there was a child with dysphasia in the classroom and was aware of what had been done the previous year. Others checked to make sure the intervention plan was properly executed or verified the teachers' knowledge about dysphasia. When they considered that knowledge to be inadequate, they either informed the teachers themselves or made sure the teachers received information specifically about dysphasia, such as written documents and audiovisual materials. In addition, more than one-third of the parents reported that they played a liaison role either among the school personnel or between the school milieu and the medical system. For example, one parent provided a pencil adapter and instructed the teacher in how it worked. Sometimes parents informed new teachers, specialist teachers, or school personnel about their child's condition and what measures needed to be in place to help the child function well in the classroom. Because this information was not transmitted from one staff member to another, parents were obliged to adopt such practices; otherwise, they said, the uninformed teacher would have found it harder to understand their child's behaviours and dysphasia and to intervene appropriately. This put an additional burden on the parents and obliged many of them, every year, to take up the work of creating awareness, supervising, informing, and training, all over again.

In addition, parental practices dealt more directly with the classification and diagnosis of their child. Sometimes a parent did not agree with the child's classification and took steps to have it changed. In some cases, parents were shocked to learn that their child's success in class resulted in the school no longer considering the child to have dysphasia, such that the child then lost the services that had facilitated this success. In each case, parents went to the school administration and took action to ensure their children's rights were respected.

Finally, some parents took advantage of various meetings to offer their support and make their presence known. They wanted the school to know they were doing everything in their power to help their children. They noted that the school personnel reacted to their involvement in a variety of ways-some were surprised and reassured, whereas others were disturbed by this presence. In summary, these communication practices led parents to say that they were defending their children's rights and that they experienced this situation as a battle that had to be re-engaged every year.

\section{Practices Related to Obligations and Support to the Child (Dimension 1)}

The obligations and support practices mainly dealt with the child's physical, social, and emotional well-being. Table 4 lists the practices that emerged from the parents' statements. All of the parents spoke about the support they gave their children. Thus support took many forms such as medical follow-up, emotional support, and parental involvement in different leisure activities. The most often cited was medical follow-up. This consisted either of doing speech therapy to help the child develop language skills and be better able to communicate with others or occupational therapy to improve the child's motor skills. Sometimes it consisted of pursuing assessments to get a clear picture of the child's difficulties and strengths. They were consequently very much involved because it was their job, on one hand, to apply at home the therapies needed to stimulate the child, and on the other hand, to act as conveyors of information from one professional to another: 
Table 4

Practices Related to the Obligations and Support Dimension

\begin{tabular}{lcc}
\multicolumn{1}{c}{ Dimensions } & Number of Sense Units & Number of Participants \\
\hline Ensure medical follow-up & 15 & 9 \\
Provide emotional support & 10 & 7 \\
Promote social integration & 6 & 5 \\
Become informed on dysphasia & 6 & 4 \\
Prepare for the inclusion & 5 & 2 \\
Ensure the child's well-being and safety & 4 & 3 \\
Total & 46 & 11 \\
\hline
\end{tabular}

When my child sees the speech therapist, he doesn't go alone; I go, too. I take notes, she trains me, and then we repeat the exercises all week. (Parent 3)

This medical follow-up therefore required their personal commitment, whether in terms of transportation, time, or money. It added to their burden, especially considering their responsibilities to care for and support other children in the family. The second point that emerged was that of emotional support. This involved encouraging and helping the child and offering consolation when things did not go well at school. It also involved ensuring the child's safety and intervening if necessary:

It means listening to our child and noticing if she's sending out messages; if she's talking about any problems. So, we want to make sure there's nothing. She tells us if she got a bad grade, a good grade. We try to understand, to follow her day, what she learned, what affected her... (Parent 8)

Parents also adopted practices to help their children integrate socially by explaining to them how to behave with their friends, by signing them up for activities, or even by becoming directly involved in these activities as a coach or leader. The aim of these practices was to help their children be part of a group without experiencing discrimination.

\section{Practices Related to Involvement in Schoolwork at Home (Dimension 4)}

This dimension includes the practices parents adopted for monitoring and becoming involved in the child's schoolwork at home. All the parents considered that helping their child with studies and homework was part of their role. Besides providing a space for the child to do homework, they verified that the child had properly understood the instructions, and they repeated the lessons several times to make sure the child remembered the material. They also made sure the task had been properly done. All this was part of their daily responsibilities because a child with dysphasia has more trouble than other children in getting organized, learning new concepts, and transferring them to new situations:

We never stop. I have two children with dysphasia. Each child has two to three hours of homework every night. For the English homework, they need to look up every word in the dictionary, every term, and with these words they need to try to make sentences. When they copy the drafts, they copy the mistakes. Everything has to be supervised. (Parent 6)

On top of the workload created by this supervision of studies and homework, parents encountered other problems. Sometimes children with dysphasia forgot to bring home the material they needed to do their lessons and homework. This forgetting may be related to the characteristics of dysphasia, but it may also be related to how the child is supported in class. For example, the teacher may give instructions about the lessons and homework while the child with dysphasia is absent from the room for a session of special education, and therefore the child does not have the information needed to do the homework properly. The parents had 
to find ways of compensating for this problem. Sometimes they asked the teacher to review with the child the material in the schoolbag, but the responses they received were not always positive. Some parents also reported having difficult interactions with their child during the period of lessons and homework, and so they chose to maintain a good relationship with the child even if it meant that the child did not complete the homework assignment:

I'm a mother who requires her children to do their work, but I won't sit at the table with my son and say, "listen, you're going to work for two hours," if I see that he is discouraged and tired. I knew just how far he could go. So, I'd help him, and when I saw that he'd had enough, I wrote a note in the journal. (Parent 4)

\section{Practices Related to Participation in Decision-making and Advocacy (Dimension 5)}

In the dimension participation in decision-making and advocacy, we considered only situations parents reported related to their interactions with administrative or legal authorities, excluding the school administration. In the literature, authors used the term "advocacy" to refer to these practices, meaning that parents were defending their children's rights.

What parents referred to most often were "requests or representations made to administrative authorities." More than half of them adopted this practice. This occurred when they came up against unsatisfactory responses from the school team. Of course they discussed these situations first with the school administration, but then they contacted the educational advisor or the directors of their school board (department of support services) if they were dissatisfied with the information they were given. The person they communicated with most often was the educational advisor for school adaptation, either to obtain information or to request services, adaptations, or modifications to the practices of members of the school teams:

I didn't know where to turn anymore, so I met with the educational advisor to find out what would happen, what he would receive in terms of support, what they were going to do for M....The role I played was really to go get more information, which I then transmitted to the school administration. (Parent 10)

The formal committees, which less than half the parents were involved in, were committees mandated by the law on education (school committees, advisory committee on students with disabilities or with learning or adjustment problems; EHDAA). This involvement was motivated by two objectives: (a) to gain a better understanding of the legal and administrative workings of the school system and (b) to make the school commission's directors aware of the situations encountered by these children in their schools.

\section{Practices Related to Family Involvement in School Life (Dimension 3)}

Parents' availability varied from one family to another depending on whether the family had two parents working full-time, had many children, or had only one parent working outside the home. These differences explained why some parents were less involved in school.

The point raised most often was that of volunteering in the classroom. Parent volunteers helped the teacher with a variety of activities. For example, sometimes they read to the children or helped the teacher in a workshop. Another form of volunteering involved helping the school prepare for a show or a vaccination campaign. The intention behind these practices was to show the teacher that the parent was available.

Some parents reported that they had expressed their wish to become involved in the classroom, but that this offer was not always positively received or the teacher or school ad- 
ministration never contacted them. One parent described how he had to cultivate a relationship with the school team in order for them to finally accept his help:

At first they were afraid. They were even worried if I looked in the window to see if my child was working, what they were doing with him. I had to bide my time, stay in my place and trust the teacher. The teachers know me now. We all respect each other's knowledge. (Parent 3)

We should point out that in the interviews all the parents spoke about ways to deal with teachers and school personnel. They did not want to offend them. Also, the teacher's perceptions of them were important. This explained some of the practices parents adopted to make themselves known and show their availability.

\section{Practices Related to Community Partnership (Dimension 6)}

Community partnership practices consisted of taking actions to integrate their child into the community and obtain the support of community organizations and government agencies (e.g., health, social services). This dimension contained the fewest sense units, and very few parents referred to it. For those who did, it usually referred to their joining an association that works with children and defends the rights of people with dysphasia. Membership in such an association gave them opportunities to attend seminars or conferences on dysphasia, inclusive schooling, or social integration. Meeting other parents going through similar experiences also encouraged some parents to persist in their practices. However, not all parents were comfortable joining mutual support groups. Some were worried that this would only lead to stigmatization of their children.

\section{Discussion}

Several findings emerged from our study. First, the results showed that Epstein's typology can be applied to the practices of parents of children with dysphasia. This typology, to our knowledge, has not previously been used to study parental involvement in inclusive schooling. Moreover, we did not have to add new dimensions to this typology as we were able to categorize all parental practices in the existing dimensions. Indeed, this typology is clearly applicable to the experience of parents of children with dysphasia integrated into a regular class. Our data allowed us to illustrate Epstein's typology in a situation for which it was not originally intended. Furthermore, the practices identified were similar to those found in the literature.

Our results also showed that the dimensions are interconnected, that is, they are not independent of each other. Indeed, a practice belonging to one dimension can stem from or be explained by a practice found in another. For example, parents may meet with the teacher (dimension 2) to learn how to help their child with lessons or homework (dimension 4). Or parents may attend an association's information session (dimension 6) or go to speech therapy sessions either in private practice or at a rehabilitation centre (dimension 1) to gain a better understanding of their child's difficulties and then be able to explain them to the teacher (dimension 2).

Similarly, we observed that a dimension consists of numerous practices and that these can vary from one parent to another. Moreover, the same practice can be implemented with different intentions. For example, parents may have different objectives for getting involved in decision-making committees (dimension 5). Some might want to make others aware of their child's presence, while for others it may be a way of becoming familiar with the system. Conversely, one intention can be represented by different practices. Thus the parent who, in meeting with a teacher, makes his or her availability known (dimension 2) and the one who 
volunteers (dimension 3) both want to show they are present in their child's life. Studies that have examined inclusion from the parents' perspective have obtained similar results (i.e., Bennett et al., 1998; Brophy et al., 1998; Grove \& Fisher, 1999; Leyser \& Kirk, 2004; Rousseau et al., 2009). For example, some parents advocate for inclusion at school and outside the school walls, but how they advocate will vary depending on their expectations, beliefs, and the situation. Therefore, it is important for school staff to understand the importance of looking not only at parents' practices, but also at the intention underlying the practices.

Finally, the responses gathered from the parents allowed us to identify factors that influenced their practices. These were of two types: individual and environmental. Individual factors included the parent's beliefs, perceptions related to the child (i.e., strengths, weaknesses, potential), expectations of the teacher and the school, and vision of his or her own role and those of others. Added to these factors were the parent's own experiences as a student, as a parent to another child with or without disabilities, or even as a professional. From the parents' statements, it was clear that these experiences influenced their view of the situation and the practices they implemented. For example, a parent who was himself a teacher explained that he was outraged by the answers he was given by school personnel that he sometimes knew to be wrong. These findings were consistent with those in the literature (i.e., Bennett et al., 1998; Beveridge, 2005; Brophy et al., 1998; Cook \& Swain, 2001; Erwin \& Soodak, 2008; Grove \& Fisher, 1999; Leyser \& Kirk, 2004; Pivik et al., 2002; Rousseau et al., 2009). For example, parents who choose inclusive schooling expect their child to have the same opportunities as other students: to learn and to develop social skills in a climate of respect for the child's differences. If parents observed a gap in the support provided or a lack of openness regarding their child, they developed various practices to improve the situation.

Environmental factors referred to the environments in which the child with dysphasia was functioning: home and school. Factors in the family environment included the number of children, the type and severity of the child's dysphasia, other children with learning difficulties, and whether the mother was working or not. Factors related to the school environment could be structural, such as the child's classification, the support provided to the child and to the teacher, and the availability of professionals, or they could relate to the attitudes of the school professionals. Indeed, parents made many comments about needing to be tactful when speaking with school professionals, on how those workers judged them, and on the lack of openness of the school staff toward professionals from other fields. Many said they had adopted practices to compensate for gaps in the educational environment. These factors caused parents to adjust their practices, placing a heavier burden on them. The environmental factors that emerged from this study corresponded to those found in other studies (i.e., Beveridge, 2005; Evans \& Lunt, 2002; Leyser \& Kirk, 2004; Pivik et al., 2002) and are identified by many authors as essential conditions for successful inclusion (i.e., Andrews \& Lupart 2000; Beveridge, 2005; Hick \& Thomas, 2008; Rousseau, 2010; Sands et al., 2000; Snell \& Brown, 2005; Turnbull et al., 2006). These factors may facilitate or complicate the achievement of inclusion objectives for students with dysphasia. The presence or absence of these conditions can lessen or increase the parents' burden.

In summary, we were able to answer our research question by identifying the practices parents of children with dysphasia adopted when they become involved in their child's school experience. We also identified factors influencing these practices and how parents adjust their involvement accordingly. Based on these results, we are able to propose some recommendations. First, it is important that all official authorities (e.g., ministries, school commissions, associations, unions) recognize the value of the family-school relationship, not only in writing, but also in training and practice. For example, required (not optional) courses on the family-school relationship and on communication particularly with parents of children with disabilities would help future teachers understand the significance of certain practices. 
Agencies working with parents, for their part, could make parents more aware of certain realities in the school system. On the other hand, teachers should have the opportunity, both in their initial training and in continuing education, to become knowledgeable about students with special needs including those with dysphasia. Not only would this lessen the burden on parents, but it would also help teachers respond more rapidly to students' needs. Finally, better knowledge of laws and policies regarding inclusion, on the part of both parents and school personnel, would certainly help reduce some confusion around their interpretation.

\section{Limitations and Future Research}

This study had certain limitations. Clearly, the low number of participants precludes any generalization of the results to the population as a whole; however, generalization is not the goal of exploratory research. Also, the parents came from school districts that had different ideas about inclusion and the support required for its success, which could have an impact on the parents' practices. Parents' levels of experience with the school system also varied.

Strategies to overcome these limitations could certainly be incorporated into the design of future studies. Meanwhile, the results of this study suggest other interesting avenues for further exploration. We have indeed identified parental practices; however, we know very little about the ways in which parents carry out these practices. Indeed, several spoke about the attitudes they encountered in others and how these offended them. This suggests that behaviours and attitudes are very important to parents. We did not explore this avenue. More indepth knowledge of these interactions might yield a better understanding of the parentteacher relationship and its repercussions. Finally, some of the parents' statements lead us to believe that there could be some value in exploring a possible connection between parents' own experiences and the practices they adopt in support of their children.

\section{References}

Andrews, J., \& Lupart, J. (2000). The inclusive classroom: Educating exceptional children. Scarborough, ON: Nelson Canada.

Beaulieu, L., \& Buttiens, B. (2005). Trouble primaire du langage/dysphasie: Une définition actualisée, une démarche diagnostique novatrice et des outils cliniques. [TPL: New definition, innovative diagnostic approach and clinical tools]. Fréquences, 17(3), 8-12.

Beauregard, F. (2002). Perceptions du milieu scolaire par des parents d'enfants dysphasiques intégrés en classe ordinaire au primaire. (Unpublished master's thesis). Montreal, QC: Université de Québec à Montréal.

Beauregard, F. (2006). Représentations sociales des parents et des enseignants de leurs rôles dans l'intégration scolaire d'un élève dysphasique en classe ordinaire au primaire. (Doctoral dissertation). Montreal, QC: Université de Montréal. Retrieved from http://atrium.bib.umontreal.ca/

Bennett, T., Lee, H., \& Lueke, B. (1998). Expectations and concerns: What mothers and fathers say about inclusion. Education and Training in Mental Retardation and Developmental Disabilities, 33(2), 108-122. Retrieved from catalogue.nla.gov.au/Record/294571

Beveridge, S. (2005). Children, families and schools: Developing partnerships for inclusive education. New York, NY: RoutledgeFalmer.

Botting, N., \& Conti-Ramsden, G. (2008). The role of language, social cognition, and social skill in the functional social outcomes of young adolescents with and without a history of SLI. British Journal of Developmental Psychology, 26, 281-300. doi:10.1348/026151007X235891

Bouchard, J.-M., \& Kalubi, J.-C. (2003). Les difficultés de communication entre intervenants et parents d'enfants vivant avec des incapacités. [Communication difficulties between professionals and parents of children with disabilities]. Éducation et francophonie, 31(1), 108-129. Retrieved from www.acelf.ca/c/revue/sommaire.php?id=4

Brophy, K., Webb, P., \& Hancock, S. (1998). The process of integration in childcare: Reflections of parents and teachers. Canadian Journal of Research in Early Childhood Education/Revue Canadiennne de l'Étude en Petite Enfance, 5(1), 107-114. 
Catts, H. W., Bridges, M. S., Little, T. D., \& Tomblin, B. J. (2008). Reading achievement growth in children with language impairments. Journal of Speech, Language, and Hearing Research, 51, 15691579. doi:10.1044/1092-4388(2008/07-0259)

Christenson, S., \& Reschly, A. L. (2009). Handbook of school-family partnerships. New York, NY: Routledge.

Coleman, P. (1998). Parent, student and teacher collaboration: The power of three. Thousand Oaks, CA: Sage.

Conseil de la famille et de l'enfance. (2001). Pour une plus grande complicité entre les familles et l'école. Sainte-Foy, QC: Author.

Conseil supérieur de l'éducation. (1996). L'intégration scolaire des élèves handicapés et en difficulté. Sainte-Foy, QC: Author.

Conseil supérieur de l'éducation. (2002). L'organisation du primaire en cycles d'apprentissage: Une mise en oeuvre à soutenir. Sainte-Foy, QC: Author.

Conti-Ramsden, G., \& Botting, N. (2008). Emotional health in adolescents with and without a history of specific language impairment (SLI). Journal of Child Psychology and Psychiatry, 49(5), 516-525. doi:0.1111/j.1469-7610.2007.01858.x

Cook, T., \& Swain, J. (2001). Parents' perspectives on the closure of a special school: Towards inclusion in partnership. Educational Review, 53(2), 191-198. doi:10.1080/00131910120055615

Coster, F. W., Goorhuis-Brouwer, S. M., Nakken, H., \& Spelberg, H. C. L. (1999). Specific language impairments and behavioural problems. Folia Phoniatrica et Logopaedica, 51(3), 99-107. doi:10 $.1159 / 000021484$

Crozier, G. (2000). Parents and schools: Partners or protagonists? Sterling, VA: Trentham Books Limited.

Denzin, N., \& Lincoln, Y. (2005). Handbook of qualitative research. London, UK: Sage.

Epstein, J. (1992). School and family partnerships. In M. C. Alkin (Ed.), Encyclopedia of educational research (6th ed.; pp. 1139-1151). New York, NY: Macmillan.

Epstein, J. (2001). School, family and community partnerships. Boulder, CO: Westview Press.

Epstein, S. A., \& Phillips, J. (2009). Storytelling skills of children with specific language impairment. Child Language Teaching \& Therapy, 25(3), 285-300. doi:10.1177/0265659009339819

Erwin, E. J., \& Soodak, L. C. (2008). The evolving relationship between families of children with disabilities and professionals. In T. C. Jimenez \& V. L. Graf (Eds.), Education for all: Critical issues in the education of children and youth with disabilities (pp. 35-69). San Francisco, CA: Jossey-Bass.

Evans, J., \& Lunt, I. (2002). Inclusive education: Are there limits? European Journal of Special Needs Education, 17(1), 1-14. doi:10.1080/08856250110098980

Fan, X., \& Chen, M. (2001). Parental involvement and students' academic achievement: A meta-analysis. Educational Psychology Review, 13(1), 1-22. doi:10.1023/A:1009048817385

Ferouhi, V. G. (2007). Written language difficulties in language-learning disabled fourth and fifth graders: An evaluative study in a New Jersey school district. Dissertation Abstracts International: Section B: The Sciences and Engineering, 76(7-B), 3754.

Fujiki, M., Brinton, B., \& Todd, C. (1996). Social skills of children with specific language impairment. Language, Speech, and Hearing Services in Schools, 27, 195-202. Retrieved from http://lshss .asha .org/

Government of Quebec. (1999). Education Act. Quebec City, QC: Author.

Grove, K., \& Fisher, D. (1999). Entrepreneurs of meaning: Parents and the process of inclusive education. Remedial and Special Education, 20(4), 208-215. doi:10.1177/074193259902000404

Hammer, C. S., Tomblin, J. B., Zhang, X., \& Weiss, A. (2001). Relationship between parenting behaviours and specific language impairment in children. International Journal of Language \& Communication Disorders, 36(2), 185-205. doi:10.1080/13682820010019919

Hick, P., \& Thomas, G. (2008). Inclusion and diversity in education. Four-volume set. London, UK: Sage.

Hoffman, L., \& Gillam, R. (2004). Verbal and spatial information processing constraints in children with specific language impairment. Journal of Speech, Language, and Hearing Research, 47, 114-125. doi:10.1044/1092-4388(2004/011)

Hoover-Dempsey, K. V., Walker, J. M. T., Sandler, H. M., Whetsel, D., Green, C. L., Wilkins, A. S., \& Closson, K. (2005). Why do parents become involved? Research findings and implications. Elementary School Journal, 106(2), 105-131. doi:10.1086/499194

Jupsin, A. (1996). Dysphasie(s). Parents: Partenaires indispensables. (Unpublished master's thesis). Liège, Belgium: University of Liège. 
Kabano, J. (2000). Les représentations sociales d'enseignantes et d'enseignants des classes ordinaires du primaire à propos des élèves handicapés. (Unpublished doctoral dissertation). Université du Québec à Rimouski/Université du Québec à Montréal, Rimouski, QC.

Kelso, K., Fletcher, J., \& Lee, P. (2007). Reading comprehension in children with specific language impairment: An examination of two subgroups. International Journal of Language \& Communication Disorders, 42(1), 39-57. doi:10.1080/13682820600693013

Knox, E. (2002). Educational attainments of children with specific language impairments at year 6. Child Language Teaching \& Therapy, 18, 103-124. doi:10.1191/0265659002ct230oa

Knox, E., \& Conti-Ramsden, G. (2003). Bullying risks of 11-year-old children with specific language impairment (SLI): Does school placement matter? International Journal of Language \& Communication Disorders, 38(1), 1-12. doi:10.1080/13682820304817

Lareau, A. (1997). Social-class differences in family-school relationships: The importance of cultural capital. In H. Halsey, P. Brown, \& A. Stuart Wells (Eds.), Education: Culture, economy, and society (pp. 703-717). Oxford, UK: Oxford University Press.

Larrivée, S. J., Kalubi, J.-C., \& Terrisse, B. (2006). La collaboration école-famille en contexte d'inclusion: Entre obstacles, risques et facteurs de réussite. [Family-school collaboration in inclusion context: Between obstacles, risks and success factors]. Revue des sciences de l'éducation, 32(3), 525-543. Retrieved from id.erudit.org/iderudit/016275ar

Lawrence-Lightfoot, S. (1978). Worlds apart: Relationships between families and schools. New York, NY: Basic Books.

Leyser, Y., \& Kirk, R. (2004). Evaluating inclusion: An examination of parent views and factors influencing their perspectives. International Journal of Disability, Development and Education, 51(3), 271-285. doi:10.1080/1034912042000259233

Lincoln, Y. S., \& Guba, E. G. (1985). Naturalistic inquiry. Newbury Park, CA: Sage.

Lipsky, D. (1989). The roles of parents. In D. Lipsky \& A. Gartner (Eds.), Beyond separate education: Quality education for all (pp. 159-180). Baltimore, MD: Paul H. Brookes.

Lussier, F., \& Flessas, J. (2005). Neuropsychologie de l'enfant: Troubles développementaux et de l'apprentissage. Paris, France: Dunod.

Miles, M. B., \& Huberman, A. M. (2003). Analyse des données qualitatives (2nd ed.). Brussels, Belgium: De Boeck.

Ministère de l'Éducation, du Loisir et du Sport du Québec. (2010). Rencontres des partenaires en éducation: Document d'appui à la réflexion. Quebec City, QC: Government of Quebec.

Ministère de l'Éducation du Québec. (1999). Une école adaptée à tous ses élèves. Quebec City, QC: Government of Quebec.

Ministère de l'Éducation du Québec. (2003a). Programme de formation de l'école québécoise: Votre enfant au primaire, information aux parents. Quebec City, QC: Government of Quebec.

Ministère de l'Éducation du Québec. (2003b). Les difficultés d'apprentissage à l'école: Cadre de référence pour guider l'intervention. Quebec City, QC: Government of Quebec.

Ministère de l'Éducation du Québec. (2004). Rapprocher les familles de l'école primaire. Quebec City, QC: Government of Quebec.

Montgomery, J. W. (2006). Real-time language processing in school-age children with specific language impairment. International Journal of Language \& Communication Disorders, 41(3), 275-291. doi:10.1080/13682820500227987

Muhr, T. (2002). Qualitative data analysis workshop: Using ATLAS.ti (Version 4) [Computer software]. Berlin: Technical University.

Nippold, M. A., \& Schwarz, I. E. (2002). Do children recover from specific language impairment? International Journal of Speech-Language Pathology, 4(1), 41-49. doi:10.1080/14417040210001669221

Ordre des orthophonistes et audiologistes du Québec. (2010). Définition de la dysphasie. Retrieved from http://www.ooaq.qc.ca/Fiches/dysphasie.htm.

Organisation de coopération et de développement économique, OCDE. (1995). L'intégration scolaire des élèves avec des besoins particuliers. Paris, France: Author.

Paillé, P., \& Mucchielli, A. (2008). L'Analyse qualitative en sciences humaines et sociales. Paris, France: Armand Colin.

Palikara, O., Lindsay, G., \& Dockrell, J. E. (2009). Voices of young people with a history of specific language impairment (SLI) in the first year of post-16 education. International Journal of Language \& Communication Disorders, 44(1), 56-78. doi:10.1080/13682820801949032 
Peets, K. F. (2009). The effects of context on the classroom discourse skills of children with language impairment. Language, Speech, and Hearing Services in Schools, 40, 5-16. doi:10.1044/0161-1461 (2008/07-0012)

Pivik, J., McComas, J., \& Laflamme, M. (2002). Barriers and facilitators to inclusive education. Exceptional Children, 69(1), 97-107. Retrieved from http://www.cec.sped.org/Content/NavigationMenu /Publications2/ExceptionalChildren/default.htm

Pratt, C., Botting, N., \& Conti-Ramsden, G. (2006). The characteristics and concerns of mothers of adolescents with a history of SLI. Child Language Teaching and Therapy, 22(2), 177-196. doi:10.1191 /0265659006ct301oa

Proctor-Williams, K., Fey, M. E., \& Loeb, D. F. (2001). Parental recasts and production of copulas and articles by children with specific language impairment and typical language. American Journal of Speech-Language Pathology, 10(2), 155-168. doi:10.1044/1058-0360(2001/015)

Riches, N. G., Tomasello, M., \& Conti-Ramsden, G. (2005). Verb learning in children with SLI: Frequency and spacing effects. Journal of Speech, Language, and Hearing Research, 48, 1397-1411. doi:10.1044/1092-4388(2005/097

Rousseau, N. (Ed.). (2010). La pédagogie de l'inclusion scolaire. Pistes d'action pour apprendre tous ensemble. Quebec, QC: Presses de l'Université du Québec.

Rousseau, N., Dionne, C., Vézina, C., \& Drouin, C. (2009). L'intégration scolaire d'enfants ayant une incapacité: Perceptions des parents québécois. [Inclusion of children with disabilities: Quebecois parents' perceptions]. Canadian Journal of Education/Revue canadienne de l'éducation, 32(1), 34-59. Retrieved from http://www.csse-scee.ca/CJE

Saint-Pierre, T. (1997). Étude qualitative sur l'impact de vivre avec un enfant dysphasique pour des parents vivant en région éloignée. (Unpublished master's thesis). Montreal, QC: University of Montreal.

Sands, D. J., Kozleski, E. B., \& French, N. K. (2000). Inclusive education for the 21st century. Belmont, CA: Wadsworth/Thompson Learning.

Sharrock, A. (1970). Home/school relations: Their importance in education. London, UK: Macmillan and Co.

Simkin, Z., \& Conti-Ramsden, G. (2009). 'I went to a language unit': Adolescents' views on specialist educational provision and their language difficulties. Child Language Teaching \& Therapy, 25(1), 103-121. doi:10.1177/0265659008098663

Snell, M., \& Brown, F. (2005). Instruction of students with severe disabilities (6th ed.). Upper Saddle River, NJ: Prentice Hall.

Thordardottir, E., Kehayia, E., Lessard, N., Sutton, A., \& Trudeau, N. (2010). Typical performance on tests of language knowledge and language processing of French-speaking 5-year-olds. Canadian Journal of Speech-Language Pathology and Audiology, 34(1), 5-16. Retrieved from http://www .caslpa.ca/english/resources/cjslpa_home.asp

Törnqvist, M. C., Thulin, S., Segnestam, Y.., \& Horowitz, L. (2009). Adult people with language impairment and their life situation. Communication Disorders Quarterly, 30, 237-254. doi:10.1177 $/ 1525740108326034$

Turnbull, A., Turnbull, H. R., Erwin, E., \& Soodak, L. (2006). Families, professionals, and exceptionality: Positive outcomes through partnerships and trust (5th ed.). Upper Saddle River, NJ: Prentice Hall.

Van der Maren, J.-M. (1995). Méthodes de recherche pour l'éducation. Montreal, QC: Les Presses de l'Université de Montréal.

Wadman, R., Durkin, K., \& Conti-Ramsden, G. (2008). Self-esteem, shyness, and sociability in adolescents with specific language impairment (SLI). Journal of Speech, Language, and Hearing Research, 51, 938-952. doi:10.1044/1092-4388(2008/069)

\section{Author's Note}

Correspondence concerning this article should be addressed to France Beauregard, Université de Sherbrooke, Faculté d'éducation, 2500 boul. de l'Université, Sherbrooke, QC, J1K 2R1. Email: France.Beauregard@USherbrooke.ca 